Journal of Applied Biology \& Biotechnology Vol. 5 (03), pp. 068-071, May-June, 2017

Available online at http://www.jabonline.in

DOI: $10.7324 / \mathrm{JABB} .2017 .50312$

(cc) EY-NC-SA

\title{
Effect of growth regulators on callus morphology of Rice anther culture
}

\author{
Avinash Sharma*, Dalpat Lal and Monoj Sutradhar \\ University of Agricultural Sciences, GKVK, Bengaluru, India.
}

\section{ARTICLE INFO}

Article history:

Received on: 29/01/2017

Accepted on: 14/03/2017

Available online: 19/06/2017

Key words:

Anther culture, Japonica rice,

Haploids, Callus morphology,

Callus texture.

\begin{abstract}
The present investigation was undertaken to know the effect of various combination of auxin and cytokinin on callus morphology in japonica rice. As the callus induction is a prerequisite for anthers culture and finally development of haploids certain callus morphology criteria empirically identified. Among the colour of callus, this was either white or yellow. The white colour was preferred. In addition to callus growth determine empirically low, medium and high define as 1,2 and 3 respectively. Callus texture was also identified as compact and friable but compact texture was accepted as more promising. Callus morphology is an empirical which can be use to predict the regeneration ability of calli.
\end{abstract}

\section{INTRODUCTION}

Rice (Oryza sativa L.) is the world most important food supplier cereal crop after wheat and maize. It provides half of total dietary carbohydrate, especially in Asian countries and it is suitable diet for more than three billion people, supplying 50-80 $\%$ of their daily calorie intake [1]. However, traditional rice breeding methods are not sufficient to fulfill the demands of growing population. The production of haploids via anther culture represents an alternative biotechnology tool for crop improvement programs. Several advantages of haploid culture technique have been reported in the breeding program [2; 3 and 4]. Anther culture is an important technique to develop homozygous line by shortening of the breeding cycle of new varieties and allows early expression of recessive genes. Beside the advantages of using the techniques, anther culture has disadvantages and constraints, i.e., low efficiencies of callus production, low frequency of plant regeneration, and high proportion of albino plants [5, 6]. Several factors are effecting the callus texture derived from in vitro anther culture of rice are types of growth regulator along with its concentrations, genotype and microspore developmental stages [7]. Texture and colours of the calli reflect their green plantlet redifferentiation competences. The embryogenic calli which were milky white in colour and compact in texture had excellent regeneration ability. However, friable calli had poor plant regeneration ability or did not

\footnotetext{
* Corresponding Author

E-mail: avinashcau@gmail.com
}

respond at all. These results are indicated that the callus induction medium has an influence on the morphogenic competence of the induced callus, determining its regeneration capability [8]. It was reported that there are conditions in which genotypes show high callus induction has displayed poor regeneration ability and vice versa [9]. Application of higher dose of auxin sources can significantly increase the callus induction efficiency, however such calli are less in embryogenic and poor in green plant regeneration. Anthers of three rice cultivars viz, BR-3, BR-10 and BRRI Dhan 29 produced friable and compact callus texture with white in colour in $\mathrm{Z}_{2}$ media containing $2 \mathrm{mg} / \mathrm{L} 2,4-\mathrm{D}+2.5 \mathrm{mg} / \mathrm{l} \mathrm{NAA}+$ $0.5 \mathrm{mg} / \mathrm{l}$ Kinetin [10]. Many an embryogenic and nonembryogenic callus with multiple colours (white, yellow and brown) reported in rice cultivar Swat II on MS media containing different concentration of auxin and kinetin with Tryptophan [11]. The rice cultivars chinigura, kalijira, Radhuni pagal, modhumala, kataribog and mohonbhog produce compact callus texture with white in colour in media containing different concentration of 2, 4-D and NAA [12]. Anthers of $\mathrm{BC}_{2} \mathrm{~F}_{3}$ of Oryza sativa $\mathrm{L}$. $\times$ Oryza rufipogon regenerate double haploid lines through compact callus texture with light green colour in N6 media containing $2 \mathrm{mg} / \mathrm{l} \mathrm{NAA}+0.5$ $\mathrm{mg} / \mathrm{l} \mathrm{Kinetin}+2 \mathrm{mg} / \mathrm{l}$ 2, 4-D [13]. Different type of callus texture with multiple callus colour reported in rice cultivar Swarna on N6 media containing 2, 4-D, 2, 4-D + Kinetin, 2, 4-D + BAP and 2, 4D + NAA [14]. With this background the present study was aimed to know effect of growth regulators on morphological characters of callus (texture and colour) produced by japonica rice varieties through anther culture. 


\section{MATERIALS AND METHODS}

Seeds of two japonica rice varieties viz, Azucena and Moroberekan were grown under standard agronomic practices. The panicles from the plants of each variety were harvested between 6.00 to 9.00 a.m. on sunny days. Panicles were harvested when the distance between collar of flag leaf and penultimate leaf was about 10-15 cm. Panicles were wrapped in aluminum foil with a moisturized cotton plug at the base and sealed in polypropylene bags separately. Surface sterilized panicles were kept for cold pretreatment at $4^{\circ} \mathrm{C}$ for one week [15]. The anthers with miduninucleate stages were first determined by cytological test using acetocarmine staining technique. Cold treated panicles were sterilized by immersing them in $70 \%$ ethanol for 20 seconds followed by immersing in $0.2 \%$ of $\mathrm{HgCl}_{2}$ for $10 \mathrm{~min}$ and washed thoroughly with sterile water [16]. The spikelets were picked up with their open ends down by a forcep and tapped on the rim of a bottle, causing anthers in the spikelets to vibrate and fall onto surface of callus induction medium. The N6 medium supplemented with various concentration of 2, 4-D, NAA and Kinetin with $3 \%$ maltose and $0.8 \%$ agar. The cultures were placed in the dark at $23 \pm 2{ }^{0} \mathrm{C}$ with relative humidity $50-60 \%$ for callus induction.

The cultures were subculture at weekly intervals for 1020 weeks. The observations were recorded as number of anthers responded, calli texture with colour and callus growth.

Table 1: Morphological characteristics of the androgenic callus obtained from Azucena and Moroberekan

\begin{tabular}{|c|c|c|c|c|c|c|c|c|c|c|}
\hline \multirow[b]{2}{*}{ Treatments } & \multicolumn{2}{|c|}{ No. of anthers inoculated* } & \multicolumn{2}{|c|}{$\begin{array}{l}\text { No. of calli } \\
\text { obtained }\end{array}$} & \multicolumn{2}{|c|}{ Colour of callus } & \multicolumn{2}{|c|}{ Type of callus } & \multicolumn{2}{|c|}{ Callus Growth } \\
\hline & 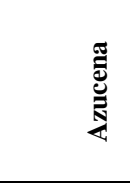 & 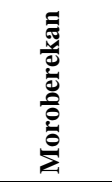 & 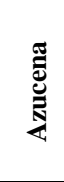 & 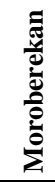 & 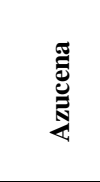 & 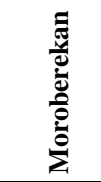 & $\underset{⿱ 乛 龰}{\mathbb{Z}}$ & 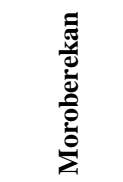 & 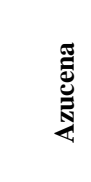 & $\begin{array}{l}\Xi \\
\frac{\pi}{0} \\
\frac{1}{0} \\
\frac{0}{0} \\
\frac{0}{0} \\
\sum\end{array}$ \\
\hline \multicolumn{11}{|l|}{ a) 2,4-D + Kinetin } \\
\hline $\mathrm{T}_{0}$ (Control) & 28.33 & 38.66 & 0 & 0 & - & - & - & - & - & - \\
\hline $\mathrm{T}_{1}(1 \mathrm{mg} / \mathrm{l}+0.5 \mathrm{mg} / \mathrm{l})$ & 34.00 & 25.00 & 2 & 0 & White & - & Compact & - & + & - \\
\hline $\mathrm{T}_{2}(1 \mathrm{mg} / \mathrm{l}+1 \mathrm{mg} / \mathrm{l})$ & 56.66 & 52.66 & 0 & 9 & - & White & - & Compact & - & + \\
\hline $\mathrm{T}_{3}(2 \mathrm{mg} / \mathrm{l}+0.5 \mathrm{mg} / \mathrm{l})$ & 69.00 & 38.66 & 2 & 3 & Yellow & White & Compact & Compact & + & + \\
\hline $\mathrm{T}_{4}(2 \mathrm{mg} / \mathrm{l}+1 \mathrm{mg} / \mathrm{l})$ & 27.66 & 36.66 & 13 & 7 & Yellow & Yellow & Compact & Compact & +++ & + \\
\hline \multicolumn{11}{|l|}{ b) NAA + Kinetin } \\
\hline$\overline{\mathrm{T}_{0} \text { (Control) }}$ & 28.33 & 38.66 & 0 & 0 & - & - & - & - & - & - \\
\hline $\mathrm{T}_{5}(1 \mathrm{mg} / \mathrm{l}+0.5 \mathrm{mg} / \mathrm{l})$ & 38.66 & 47.66 & 4 & 3 & White & Yellow & Compact & Friable & + & + \\
\hline $\mathrm{T}_{6}(1 \mathrm{mg} / \mathrm{l}+1 \mathrm{mg} / \mathrm{l})$ & 40.33 & 53.33 & 4 & 7 & White & White & Compact & Compact & + & + \\
\hline $\mathrm{T}_{7}(2 \mathrm{mg} / \mathrm{l}+0.5 \mathrm{mg} / \mathrm{l})$ & 53.00 & 45.00 & 3 & 1 & Yellow & Yellow & Compact & Compact & + & + \\
\hline $\mathrm{T}_{8}(2 \mathrm{mg} / \mathrm{l}+1 \mathrm{mg} / \mathrm{l})$ & 35.66 & 47.00 & 4 & 5 & White & White & Compact & Compact & + & + \\
\hline \multicolumn{11}{|l|}{ c) 2,4-D + NAA + Kinetin } \\
\hline$\overline{\mathrm{T}_{0} \text { (Control) }}$ & 28.33 & 38.66 & 0 & 0 & - & - & - & - & - & - \\
\hline $\mathrm{T}_{9}(1 \mathrm{mg} / \mathrm{l}+1 \mathrm{mg} / \mathrm{l}+0.5 \mathrm{mg} / \mathrm{l})$ & 38.33 & 54.66 & 0 & 5 & - & Yellow & - & Compact & - & + \\
\hline $\mathrm{T}_{10}(1 \mathrm{mg} / \mathrm{l}+1 \mathrm{mg} / \mathrm{l}+1 \mathrm{mg} / \mathrm{l})$ & 47.00 & 38.33 & 1 & 1 & White & White & Compact & Compact & + & + \\
\hline $\mathrm{T}_{11}(1 \mathrm{mg} / \mathrm{l}+2 \mathrm{mg} / 1+0.5 \mathrm{mg} / \mathrm{l})$ & 38.66 & 37.00 & 7 & 18 & White & Yellow & Compact & Friable & + & +++ \\
\hline $\mathrm{T}_{12}(1 \mathrm{mg} / \mathrm{l}+2 \mathrm{mg} / \mathrm{l}+1 \mathrm{mg} / \mathrm{l})$ & 36.00 & 41.66 & 2 & 2 & Yellow & White & Compact & Compact & + & + \\
\hline $\mathrm{T}_{13}(2 \mathrm{mg} / \mathrm{l}+1 \mathrm{mg} / \mathrm{l}+0.5 \mathrm{mg} / \mathrm{l})$ & 63.66 & 43.33 & 2 & 17 & Yellow & Yellow & Compact & Compact & + & ++ \\
\hline $\mathrm{T}_{14}(2 \mathrm{mg} / \mathrm{l}+1 \mathrm{mg} / \mathrm{l}+1 \mathrm{mg} / \mathrm{l})$ & 33.33 & 43.33 & 4 & 7 & Yellow & White & Friable & Compact & + & + \\
\hline $\mathrm{T}_{15}(2 \mathrm{mg} / \mathrm{l}+2 \mathrm{mg} / \mathrm{l}+0.5 \mathrm{mg} / \mathrm{l})$ & 53.66 & 46.00 & 5 & 8 & White & White & Compact & Compact & + & + \\
\hline $\mathrm{T}_{16}(2 \mathrm{mg} / \mathrm{l}+2 \mathrm{mg} / \mathrm{l}+1 \mathrm{mg} / \mathrm{l})$ & 57.00 & 51.66 & 7 & 12 & White & Yellow & Compact & Compact & + & + \\
\hline
\end{tabular}

Legend: * Average of 3 replication; - No callus; + low callus growth; ++ Medium growth; +++ High callus growth.
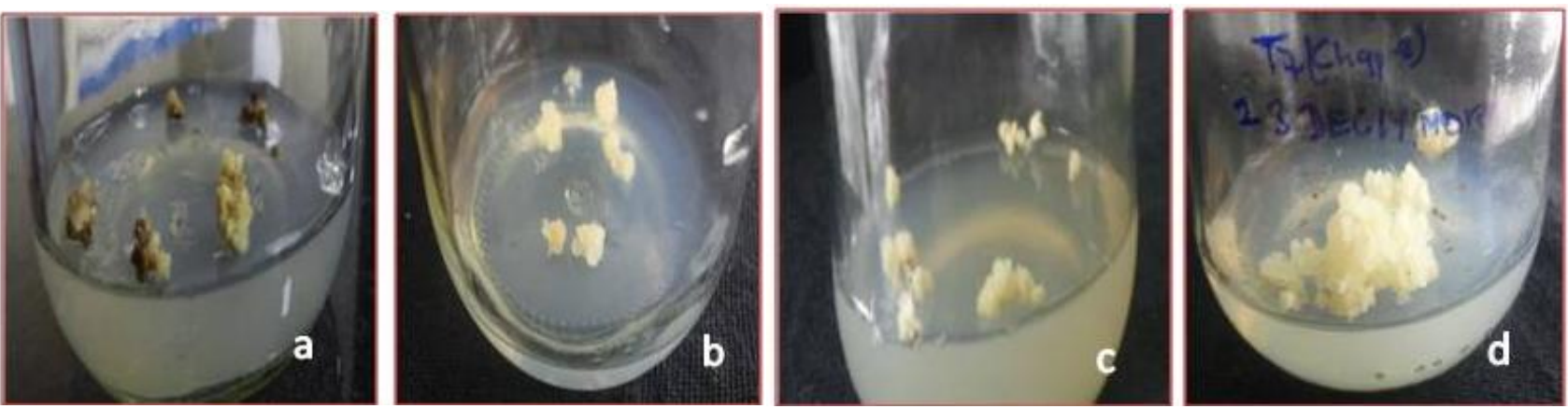

Fig.1: Callus morphology of azucena (a, b) and Moroberekan (c, d). 


\section{RESULTS AND DISCUSSION}

Rice (Oryza sativa $\mathrm{L}$., $2 \mathrm{n}=24$ ) is classified under the tribe Oryzeae, subfamily Oryzoideae of the grass family Poaceae [17]. Among cereals, it is one of the most studied, serving as staple food of more than half of the world's population [18]. Rice is composed of two subspecies: indica rice, described as tropical long grain, accounts for approximately $80 \%$ of cultivated rice, and japonica rice, with rounded and shorter grain, is more adapted to temperate climates [19].

Tissue culture technique is known as a novel means to create genetic variability and has been proposed as an excitant supplementary technique for plant which can accelerate the breeding programs through the use of new expended genetic variability. Successful application of tissue culture method involved the establishment of a more or less de-differentiated cells or tissue under defined culture condition, proliferation of a number of cells and the subsequent regeneration of plants [20]. Many new rice cultivars have been developed through biotechnological techniques like anther culture, embryo rescue and somaclonal variation [21 and 22].

\subsection{Callus texture and colour}

In the present study results obtained on morphology of callus was presented in Table 1. The cultured anthers were started turning brown after two weeks of inoculation. The first indication of callus initiation was swelling of the anther wall followed by emergence of microcalli from anther lobes. Later, callus appeared from the cut ends. This result was not surprising because it also reported changing of anther colours which is possibly due to the transition of gametophytic phase to sporophytic phase during androgenesis [23].

Irrespective of varieties, among 2, 4-D + Kinetin growth regulator combination of treatments in Azucena calli were compact and white colour obtained in only one treatment $\left(\mathrm{T}_{1}\right)$ and yellow with compact calli were obtained in the two treatments $\left(\mathrm{T}_{3}\right.$, $\mathrm{T}_{4}$ ) however, similar results obtained on $\left(\mathrm{T}_{2}, \mathrm{~T}_{3}\right)$ and $\left(\mathrm{T}_{4}\right)$ in Moroberekan respectively. Yellow calli with compact type reported in rice genotypes on N6 media containing 2, 4-D + Kinetin [24]. Friable callus texture with cream colour found in rice cultivar MR 219 on N6 media containing 2, 4-D and Kinetin either alone or in combination which was contradictory of the present study [25]. Yellow and white colour callus reported in three japonica rice varieties Hayahishiki, Fujisaka 5 and Nipponbare on N6 media containing 2, 4-D [26].

Combination of 2, 4-D + Kinetin was more effective in producing embryogenic callus compared to non-embryogenic callus [27]. Embryogenic calli with nodular structures appeared on the surface of the non-embryogenic callus. These calli tend to be light yellow to whitish in color which is slightly different from the non-embryogenic callus. Nonembryogenic calli with white, wet and friable characters were found predominantly under dark condition. It was documented that embryogenic callus displayed higher frequency of plant regeneration than the non-embryogenic one [28]. Therefore, media modifications should target the production of embryogenic callus with good regeneration ability rather than simply inducing prolific callusing, from which regeneration would not be possible [29]. Among NAA + Kinetin combination of growth regulator treatments in Azucena white calli with compact type was obtained in three treatments $\left(\mathrm{T}_{5}, \mathrm{~T}_{6}, \mathrm{~T}_{8}\right)$ and yellow calli with compact type was obtained in the one treatment $\left(\mathrm{T}_{7}\right)$ (Fig. 1a,b). This finding agrees with the earlier observations [30]. However, in Moroberekan white and compact type of calli were obtained in two treatments $\left(\mathrm{T}_{6}, \mathrm{~T}_{8}\right)$ and yellow calli with friable type were observed in one treatment $\left(\mathrm{T}_{7}\right)($ Fig. 1c, d). Yellow calli with compact and friable type reported in $\mathrm{BC}_{1} \mathrm{~F}_{1}$ anthers of (KDML105//IRBB5/KDML105) on N6 media containing NAA + Kinetin [31]. The combination of auxin and cytokinin growth regulators: 2, 4-D + NAA + Kinetin treatments in Azucena calli were white with compact obtained in four treatments $\left(T_{10}, T_{11}, T_{15}, T_{16}\right)$ and two treatments $\left(T_{12}, T_{13}\right)$ were produced yellow calli with compact and one treatment $\left(\mathrm{T}_{14}\right)$ yellow with friable type calli were obtained. In Moroberekan, white calli with compact type was produced in four treatments $\left(T_{10}, T_{12}, T_{14}\right.$, $\left.\mathrm{T}_{15}\right)$ and three treatments $\left(\mathrm{T}_{9}, \mathrm{~T}_{13}, \mathrm{~T}_{16}\right)$ was obtained yellow calli with compact type and only one treatment $\left(\mathrm{T}_{11}\right)$ was produced yellow calli with friable type. These results also supported to the earlier studied [32]. The white friable callus might be due to higher doses of hormone in the callus induction medium [33]. It was reported that hormone requirement is genotype specific and optimum level of auxin in the callus induction media required some degree of compromise between callus induction and regeneration frequency [34].

\subsection{Callus growth}

Among the 2, 4-D + Kinetin growth regulator combination that induced callus in the two varieties, one treatment in Azucena $\left(\mathrm{T}_{4}\right)$ obtained high callus growth and rest of the treatment $\left(\mathrm{T}_{1}, \mathrm{~T}_{3}\right)$ induced poor callus growth. However, in Moroberekan, poor callus growth was induced in treatments $\left(\mathrm{T}_{2}\right.$, $\mathrm{T}_{3}, \mathrm{~T}_{4}$ ). Anthers of Kyoto Asahi rice variety produced good callus growth at N6 media containing 2, 4-D + Kinetin [35]. However, $\mathrm{NAA}+$ Kinetin growth regulator combination that induced poor callus growth in both the varieties. Among the 2, 4-D + NAA + Kinetin growth regulator combination induced poor callus growth in seven treatments $\left(\mathrm{T}_{10}, \mathrm{~T}_{11}, \mathrm{~T}_{12}, \mathrm{~T}_{13}, \mathrm{~T}_{14}, \mathrm{~T}_{15}, \mathrm{~T}_{16}\right)$ in Azucena, whereas in Moroberekan highest $\left(\mathrm{T}_{11}\right)$ and moderate callus growth was obtained in treatments $\left(T_{13}\right)$ and rest of the treatments $\left(T_{9}, T_{10}\right.$, $\mathrm{T}_{12}, \mathrm{~T}_{14}, \mathrm{~T}_{15}, \mathrm{~T}_{16}$ ) was induced poor callus growth. Callus growth reported in japonica rice variety Azucena at N6 media containing 2, 4-D + NAA + Kinetin with similar grading of callus growth [36]. In conclusion embryogenic calli with compact type was predominant in both Azucena and Moroberekan varieties. Growth regulator along with its concentration has ability to produce different types of callus, colour of callus and callus growth. Therefore, types of growth regulator along with its concentration need to be considered in order to achieve high embryogenic calli and callus growth. 


\section{ACKNOWLEDGEMENTS}

Authors would like to thanks Dr. H. E. Shashidhar for providing seed materials.

Financial support and sponsorship: Avinash Sharma acknowledges DBT-HRD, New Delhi, India for providing fellowship during M.Sc. program.

Conflict of Interests: There are no conflicts of interest.

\section{REFERENCES}

1. Khush GS. Breeding rice for resistance to insects. Prot. Ecol. 1984; 7:147-165.

2. Khush, G.S., and Virmani. 1985. Breeding rice for disease resistance. In: Progress in Plant Breeding. Butterworths, United Kingdom, 1:240-279.

3. Zapata FJ. Rice anther culture at IRR1. In: Biotechnology in International Agricultural Research. Proc. of the inter RRI Center Seminar on Intl. Agric. Res. Centre and Biotechnology. Los Banos, Philippines, 1985; pp. 85-95.

4. Raina, SK, Balachandran SM, Virmani SS, Zapata FJ. Improved medium for efficient anther culture of indica rice hybrids. International Rice Research Newsletter, 1989; 1-14.

5. Tran DG, Vuong DT. Effect of different media and genotypes on anther culture efficiency of $\mathrm{F}_{1}$ plants derived from crosses between IR64 and new plant type rice cultivars. Omonrice. 2002; 10:107-109.

6. Niroula RK, Bimb HP. Effect of genotype and callus induction medium on green plant regeneration from anther of Nepalese rice cultivars. Asian J. Plant Sci. 2009; 1682-3974:1-7.

7. Rukmini M, Gundimeda JNR. In-vitro androgenesis in rice: advantages, constraints and future prospects. Rice Sci. 2016; 23(2):57-68.

8. Silva TD, Ratnayake WJ. Anther culture potential of indica rice varieties, Kurulu thuda and BG 250. Trop. Agril. Res. Ext. 2009; 12(2):53-56.

9. Talebi R, Rahemi MR, Arefi H, Nourozi M, Bagheri N. In vitro plant regeneration through anther culture of some Iranian local rice (Oryza sativa L.) cultivars. Pak. J. Biol. Sci. 2007; 10(12):2056-2060.

10. Shahnewaz S, Bari MA, Siddiqu NAE, Khatun N, Rahman MH, Haque, ME. Induction of haploid rice plants through in vitro anther culture. Pak. J. Biol. Sci. 2003; 6(14):1250-1252.

11. Bano S, Jabeen M, Rahim F, Ilahi I. Callus induction and regeneration in seed explants of rice (Oryza sativa cv. Swat-II). Pak. J. Bot. 2005; 37(3):829-836.

12. Roly, ZY, Mahmudul I, Pallob ES, Saiful IA, Shah S, Dipesh D, Mujjammil EH, Khalekuzzaman. In vitro callus induction and regeneration potentiality of aromatic rice (oryza sativa L.) cultivars in differential growth regulators. Int. J. Appl. Sci. Biotechnol. 2014; 2(2):160-167.

13. Ambarawati AD, Somantri IH, Utami DW, Apriana A, Moeljopawiro S. Rice anther culture to develop double haploid population and blast resistant lines. J. Agro. Biogen, 2009; 5(2):71-77.

14. Shukla R, Dube A, Koshy EP. Production of high quality embryogenic callus of rice. The Bioscan. 2014; 9(3):1077-1080.

15. Dalpat L, Shashidhar HE, Gowda, PHR, Ashok TH. Callus induction and regeneration from in vitro anther culture of rice (Oryza sativa L.). Int. J. Agrl. Envir. Biotechnol. 2014; 7(2):213-218.

16. Gioi TD, TUAN VD. Anther culture from crosses between rice IR64 and new plant type cultivars. Omonrice. 2004; 12:27-32.

17. Lu BR. Taxonomy of the genus Oryza (Poaceae): historical perspective and current status. International Rice Research Institute Notes. 1999; 243:4-8.

18. Food and Agriculture Organization of the United Nations. The State of Food and Agriculture 2003-2004. Agricultural Biotechnology:
Meeting the Needs of the Poor? Retrieved from www.fao.org/docrep/ on 01 June 2005.

19. Ayres NM, Park WD. Genetic transformation of rice. Crit. Rev. Plant Sci. 1994; 13(3):219-239.

20. Larkin PJ, Scrowcroft WR. Somaclonal variation a novel source of variability from cell culture for plant improvement. Theor. Appl. Genet. 1981; 60:197-214.

21. Brown DCW, Thorpe TA. Crop improvement through tissue culture. World J. Microbiol. Biotechnol. 1995; 11:409-415.

22. Zapata AFJ, Torrizo LB, Ando A. Current developments in plant biotechnology for genetic improvement: the case of rice (Oryza sativa L.). World J. Microbiol. Biotechnol. 2004; 11:393-399.

23. Guzman M, FJ Zapata-Arias. Increasing anther culture efficiency in rice (Oryza sativa L.) using anthers from ratooned plants. Plant Sci. 2000; 151:107-114.

24. Kaushal L, Sharma R, Balachandran S M, Ulaganathan K, Shenoy V. Effect of cold pretreatment on improving anther culture response of rice (Oryza sativa L.). J. Exp. Biol. Agrl. Sci. 2014; 2:234-241.

25. Paramasivam S, Law YS, Ho CL, Harikrishna JA. High frequency plant regeneration from mature seed of elite, recalcitrant malaysian indica rice (Oryza sativa L.) cv. MR 219. Acta Biologica Hungarica. 2010; 61(3): 313-321.

26. Wagiran A, Ismail I, Radziah C, Zain CM, Abdullah R. Improvement of plant regeneration from embryogenic suspension cell culture of japonica rice. J. Biol. Sci. 2008; 1727(3048):570-576.

27. Ge XJ, Chu ZH, Lin YJ, Wang SP. A tissue culture system for different germplasms of indica rice. Plant Cell Rep. 2006; 25:392402.

28. Nabors MW, Heyser JW, Dykes TA, Demott KJ. Long duration, high frequency regeneration from cereal tissue cultures. Planta.1983;157:385-391.

29. Silva TD. Indica rice anther culture: can the impass be surpassed. Pl. cell Tiss. and Org. Cult. 2010; 100(1):1-11.

30. Huang CR, Wu YH, Chen CC. Effects of plant growth substances on callus formation and plant regeneration in anther culture of rice. In: Proceedings of the International Rice Genetics Symposium, Rice Genetics, IRRI, Manila, Philippines, 1985; pp.763-761.

31. Sengsai S, Peyachoknagu S, Sripichitt P, Thongpan A, Pongtongkam P. Anther culture of BC1F1 (KDML105//IRBB5/KDM1105) hybrid to produce bacterial blight resistance doubled haploid rice. Kasetsart J. (Nat. Sci.) 2007; 41:251-261.

32. Trejo-Tapia G, Amaya UM, Morales GS, Sanchez ADJ, Bonfil BM. The effects of cold pretreatment, auxins and carbon source on anther culture of rice. Plant Cell Tiss.Org. Cult., 2002; 71:41-46.

33. He P, Shen LS, Lu, CF, Chen Y, Zhu LH. Analysis of quantitative trait loci which contribute to anther culturability in rice (Oryza sativa L.). Mol. Breed. 1998; 4:165-172.

34. Liang HM. The advance of studies on medium for anther culture of rice in china. In: Proceedings of the Symposium on Plant Tissue Culture, May 25-30, Peking, China, 1978; pp. 57-64.

35. Yamada Y, Kenji T, Eiichi T. Callus induction in rice Oryza sativa L. Proc. Japan Acad. 1967; 43(2):156-160.

36. Dalpat L. Anther culture studies in rice (Oryza sativa L.). M.Sc. (Agri.) Thesis, 2012; University Agricultural Sciences, Bangalore.

\section{How to cite this article:}

Sharma A, Lal D, Sutradhar M., Effect of growth regulators on callus morphology of Rice anther culture. J App Biol Biotech. 2017; 5 (03): 068-071. DOI: 10.7324/JABB.2017.50312 